UMR. alingy

FLEXIBILITY IN THE IMPLEMENTATION OF INTELLECTUAL PROPERTY RIGHTS

\author{
IN AGRICULTURAL BIOTECHNOLOGY
}

TROMMETTER Michel

Working Paper GAEL ; 2007-13

- July 2007 -

Institut National de la Recherche Agronomique - Université Pierre Mendès France Unité Mixte de Recherche 1215

Domaine Universitaire - BP 47 - 38040 GRENOBLE Cedex 9

Tél. : 33 (0) 476825439 - Fax : 33 (0) 476825455

E-mail : vertier@grenoble.inra.fr - http://www.grenoble.inra.fr 


\section{Flexibility in the implementation of Intellectual Property Rights in agricultural biotechnology ${ }^{1}$}

Michel Trommetter:

UMR GAEL, INRA and P. Mendès France University, Grenoble, France;

and Laboratoire d'Econometrie at the Ecole Polytechnique, Paris, France.

Address

UMR GAEL INRA UPMF

BP 47

38040 Grenoble cedex 9

France

Tel. 33476827803

Fax 33476825455

Email michel.trommetter@grenoble.inra.fr

${ }^{1}$ I am grateful to Claude Henry for his comments on this work. I also wish to thank the French Ministry of Ecology and Sustainable Development (Ministère de l'Ecologie et du Développement Durable) which financed my research. 


\section{Abstract:}

In this paper I discuss the fact that economists define optimal IP rights as a continuum of options in three dimensions: height, breadth and length. At the operational level we see the impossibility of multiplying rights indefinitely (due to prohibitive transaction costs), as well as the use of a limited number of IP tools which have led to the implementation of flexibilities. These flexibilities are designed to limit certain perverse effects of rights ill-adjusted to the characteristics of some economic sectors (agricultural biotechnologies, pharmacy, etc.). In this context, I analyse how these flexibilities are implemented in TRIPS and TRIPS+ agreements and I study the consequences for Developing Countries.

Keywords

Intellectual property right, patent, agriculture, Trips, innovation.

JEL Classification

K11 
The application of intellectual property rights and their impact on innovation are essential issues in every country's development and growth. At the WTO (World Trade Organisation), in parallel with negotiations on rules of access to goods and service markets - commonly referred to as "trade liberalization" - negotiations concern the TRIPS agreements (trade-related aspects of intellectual property). The official aim of these negotiations, especially Article 27 on patents, is to establish a minimum level of intellectual property rights at international level, in order to ensure the protection of innovations and their diffusion towards those countries that have adequate intellectual property rights. These agreements are supposed to favour the development of innovations and their commercialization world wide, to promote growth, and to reduce poverty (Article 7) ${ }^{2}$. Are things all that simple? This is what I set out to examine in this article.

In the first section, in order to understand the implications of the TRIPS agreements, I consider from a theoretical perspective the implications of intellectual property regarding the production of innovations. In the second section I then analyse the conditions required for the implementation of intellectual property rights. Finally, in the last section I present the TRIPS agreement and TRIPS+ (bilateral free trade agreements between developing countries and the USA or EU) and their positive and negative impacts on developing countries and international trade.

\section{General review of incentives to innovate and to diffuse innovations}

In economics, promoting innovation and its diffusion corresponds to the objective of "seeking an intertemporal social optimum". As Henry, Trommetter and Tubiana noted in 2003: "In situations of endogenous growth - the most suitable framework for studying the motivations and effects of inventive (or innovative) activity and technological progress -, two forms of competition are at play. First, competition for triggering innovation and taking advantage of it $^{3}$; second, competition in the

\footnotetext{
2 "The protection and enforcement of intellectual property rights should contribute to the promotion of technological innovation and to the transfer and dissemination of technology, to the mutual advantage of producers and users of technological knowledge and in a manner conducive to social and economic welfare, and to a balance of rights and obligations", Trips Agreement, Article 7.

${ }^{3}$ Or deriving the benefit of reputation, in the case of R\&D institutions where profit is not the main motivation ("open science").
} 
market for products, that is, the goods or services that innovation helps to create or improve, or whose production costs it reduces".

\subsection{Incentives for firms to innovate and to diffuse their innovations}

Which characteristics are mobilized to encourage firms to innovate and to diffuse their innovations?

\subsubsection{Incentives for firms to innovate}

If firms are to be encouraged to innovate, they have to be given incentives to invest in research and development (R\&D). In neoclassical theory, if innovation can easily be imitated ${ }^{4}$ - therefore at a low cost -, and in the absence of any other hypothesis, competition in the innovative product market is perfect; thus, at the market equilibrium, the price corresponds to the marginal cost of production. This situation does not encourage firms to innovate since they are unable to derive a return on their R\&D investments. Irrespective of how easily innovation can be imitated, innovators have to be ensured of a return on their $\mathrm{R} \& \mathrm{D}$ investments. There are several options in this respect:

* There is external funding for R\&D from government or foundations, and the firm's investments in $\mathrm{R} \& \mathrm{D}$ are nil. This provides the right conditions for combining incentives to innovate, with an innovation market, characterized by pure and perfect competition.

* Since investment in R\&D is positive, a rent needs to be created for the innovative firm. This rent is guaranteed by the recognition of an intellectual property right which, for the innovator, creates a temporary monopoly ${ }^{5}$ on the commercialization ${ }^{6}$ and diffusion of the innovation.

\footnotetext{
${ }^{4}$ We need to bear in mind that in most industries, secrecy is preferred over protection via intellectual property rights, in the vast majority of cases.

${ }^{5}$ The monopoly has to be temporary to encourage firms to adopt strategies of sequential innovations: ex ante competition, innovative monopoly, ex post competition when innovation falls into the public domain, etc.

${ }^{6}$ Any intellectual property allows the right to exclude rivals from the use of an innovation, but does not necessarily grant a use right to that innovation (e.g. development phase during authorization to commercialize drugs).
} 
The first option is certainly the most favourable from the social welfare point of view, but since external funds are not unlimited, today they are used primarily to finance research in "orphan" sectors ${ }^{7}$ and in the case of innovations in fundamental research. For instance, in 2005 the Bill and Melinda Gates Foundation invested US\$300m in research to develop a malaria vaccine ${ }^{8}$. In these external mechanisms of R\&D financing, the innovator can be compensated (remunerated) in the form of a call for tenders, a prize (Master (2004)), and so on.

To implement the second option, economists (e.g. Gilbert and Shapiro (1990)) propose that optimal property rights be found and implemented; that is, property rights whose characteristics allow for a social optimum to be achieved ${ }^{9}$. This means defining what can be protected - height of intellectual property - , for how long - length ${ }^{10}$-, and with what scope - breadth ${ }^{11}-$, and thus facilitating the creation and diffusion of innovations and of related information.

In this context the monopoly situation stemming from the intellectual property system is socially acceptable because it ensures the social optimum. To see this we need to reason in relative terms: what is the alternative to a monopoly on an innovation? - a market "without innovation". This means that with a monopoly price, fewer consumers will have access to the innovative good, compared to a competitive market (unfavourable situation for consumers). On the other hand, at the competitive market price there would be no supply function for this innovative good, due to the disincentives for the innovator to invest in R\&D (situation even more unfavourable for consumers). The monopoly is then a "necessary ill”, to achieve a second-best social optimum when it is associated with the absence of unlimited external funding of research and with optimal intellectual property rights. Theoretically, a

\footnotetext{
${ }^{7}$ An orphan sector is a sector in which the demand function never intersects with the supply function, and where the societal stakes are high in terms of global public goods, whether these pertain to the right to health, food or a good environment.

${ }^{8}$ Source: http://www.gatesfoundation.org

${ }^{9}$ For a survey of the stakes of intellectual property, see Langinier and Moschini (2002).

${ }^{10}$ The duration of intellectual property rights must be long enough to cover the irrecoverable costs of R\&D, and short enough to ensure competition in the product market conducive to new R\&D expenditures, so that future innovations can be developed.

${ }^{11}$ The scope of the patent must be sufficiently broad to limit risks of imitation, and sufficiently narrow to ensure competition in the search for future innovations.
} 
continuum of intellectual property rights exists in all three dimensions (height, length and breadth), including the absence of intellectual property rights if the height is nil.

1.1.2. Incentives for firms to diffuse their innovations and information on those innovations

The stakes involved in diffusing innovations and related information are threefold:

- it allows a maximum number of consumers to be able to benefit from the innovation; the innovation is diffused in countries in which there is a market and therefore also a demand function compatible with the innovator's supply function, as well as adequate intellectual property rights;

- it increases incentives to innovate. Favouring the diffusion of innovation towards other countries increases the size of the potential market. And the bigger the potential market, the stronger incentives to invest in $R \& D$ will be. Incentives to innovate by proposing a monopoly situation to the innovator are effective if sufficiently large local, national, regional and international markets exist;

- it increases the incentives for rival firms to innovate (in the country or in other countries) partly by informing them on protected innovations (thus limiting duplication in research) and partly by favouring spillovers and cumulative innovations. This third point is the most controversial since it depends on the scope granted to an intellectual property right ${ }^{12}$. In this respect, Henry, Trommetter and Tubiana (2003) point out that "knowledge accumulated from past innovations is a public good ${ }^{13}$ on which subsequent innovations will be based".

The decision to diffuse an innovation and/or information on an innovation in a third country will depend on various factors:

\footnotetext{
${ }^{12}$ The risk relative to spillovers that would be too great for an innovator, would be that the area of the market after diffusion of the innovation were more limited than before its diffusion.

${ }^{13}$ In the economic sense of a public good (whose use by one does not reduce its potential use by others) but not necessarily in the legal sense.
} 
- Consumers' capacity for adopting the innovation (as an intermediate or final good). Does a demand function for innovation exist? Is this demand function compatible with the innovator's supply function? The utility stemming from the consumption of the innovation as a final good is determined by the price that the consumer is willing to pay for access to the innovation (consumer's marginal utility). The utility related to use of the innovation as an intermediate consumption in a production process is more complex to measure. For instance, if use of the innovation allows the production of another good to be doubled, what are the consequences on the net income of the consumer of the innovation as an intermediate good: an increase or a reduction ${ }^{14}$

- The capacity to ensure that property rights are enforced, and therefore to limit risks of imitation. The presence of property rights in a country is necessary but not sufficient to encourage innovators to diffuse their innovations. There are asymmetries of information (moral hasard) between innovators and the country as regards its capacity to ensure that rights are enforced, and thereby to avoid opportunistic behaviours in local competitors. The innovator has to prove - put out signals attesting to - its capacity to ensure that the rights implemented are upheld.

To sum up, the size of the innovator's potential market depends on the capacity to adopt innovations in the countries concerned. This, in turn, is contingent on budgetary constraints or consumers' market power, on facilities for accessing new markets in the case of intermediate consumption (phytosanitary controls, infrastructure, etc.), and on their consequences on consumers in the country in which the innovation originated $^{15}$. If a demand function exists, the innovation will be diffused if the property

\footnotetext{
${ }^{14}$ For instance, in Mali the introduction of high-yield crop varieties into isolated villages resulted in a $100 \%$ increase in agricultural production and consequently in the collapse of farmers' incomes. This was due to a lack of access to national and international markets for the surplus production (Henry Feyt, personal paper).

${ }^{15}$ Hence, in the agricultural sector, if an innovator from country X distributes seeds in other countries and, in parallel, country X's agricultural product market opens up to competition, this will have consequences on competition between farmers in country $\mathrm{X}$ and farmers in other countries. Theoretically it can even lead to the disappearance of the agricultural sector in country $\mathrm{X}$ if production costs are too high compared to other countries. If farming dies out in country X, the same will apply to the demand for seed in that country. In this case, the innovator has to ensure that the foreign demand is sufficient.
} 
rights are credible and respected. But what are the incentives for a country to implement property rights?

\subsection{Incentives for a country to implement property rights to attract innovations and} encourage research

The implementation of intellectual property rights to attract innovations and direct foreign investments, and to boost the country's R\&D, will depend on the characteristics of each country, particularly their demand and research capacities. Hence:

- $\quad$ A developing country does not have R\&D capacities but does have a demand function that is compatible with the innovation supply function of the North. In this case, the country is urged to establish intellectual property rights in order to encourage the innovator in the North to diffuse its innovation in the South at the Northern market price, that is, at the average cost or the monopoly price of his or her innovation. The developing country can then hope for increasing direct foreign investments and a "good" development dynamic. This development option is heavily dependent on foreign investment. There is a risk of the growth being entirely contingent on an increase in the trade deficit, which is not sustainable. For such development to be sustainable, it has to be accompanied by measures such as technology transfer (primarily of production, in order to favour local development).

- A country has neither R\&D capacities nor a demand function for an innovation from the North that is compatible with the market price in the North. There are two possibilities:

o The country will be willing to establish intellectual property rights if it secures a guarantee from the innovator in the North of access to its innovation at a differentiated price - e.g. the marginal production cost, to allow access by the most people possible to the innovative product - or of external funding (foundations). Uncertainty nevertheless remains on the sustainability of the diffusion of the innovation. 
o In the absence of guarantees on the diffusion of innovation, it will be in a country's interests not to set up a system of intellectual property rights. In this way it may have access to imitations produced in countries where intellectual property rights do not exist, or to innovations produced in the North for the South and financed by foundations or public funds ${ }^{16}$. In each country the implementation of rights blocks access to imitations.

Direct foreign investments should then be increasing and create a development dynamic dependent on foreign countries (either in the North or else imitators in the South). This situation is sustainable if the diffusion of innovations and imitations is accompanied by an increase in wealth via technology transfer, primarily production technology. There is nevertheless still the risk of redistribution of surplus (royalties) which may exclusively benefit innovating countries or imitators, and therefore contribute very little to the growth of countries in the South.

- If a country has no research capacities but does have imitation capacities, then irrespective of its demand capacities, it will not be encouraged to set up an IP system. To avoid too much dependence on foreign innovations, it prefers to wait for local firms to develop their research activities in such a way as to have a more favourable allocation of resources, that is, with fewer royalties to pay to countries in the North. During this transition phase between imitation activities and research activities, firms carry on copying and diffusing their imitations in the local market and in the markets of countries which have not adopted IP rights ${ }^{17}$.

- $\quad$ Finally, if a country has R\&D activities and a demand function, implementation of IP rights stands to reason and firms' objective is to produce innovations to compete with those of others in the international market. Today India is developing a pharmaceutical industry based on innovation and no longer on imitation; this has required amendments to Indian legislation protecting pharmaceutical inventions.

\footnotetext{
${ }^{16}$ For instance, in 2005 the Bill and Melinda Gates Foundation financed the distribution of Aids antiretroviral drugs in Africa for an amount of over US\$30m.

${ }^{17}$ In 1968 Germany introduced pharmaceutical patents in its national laws; Italy and Sweden followed suit two years later. Japan recognized patentability in 1976 and Switzerland in 1977 only.
} 
The trade-off for a country is between setting up IP rights to boost research at national level, or setting up IP rights to promote imports of foreign innovations. This is a tricky choice: on the one hand it is a matter of setting up weak enough rights to have possibilities of development of research activities independent of the North, but at the same depriving itself of access to innovations of the North - bar those financed by foundations or public funds; on the other hand it consists in implementing rights that are strong enough to guarantee access to innovations, but at the same time deprive the country of research capacities in the long term. This is a particularly difficult decision to make since the dependence of the diffusion of innovations on outside innovators can be a source of social underefficiency in the long term, depending on the evolution of its research and imitation capacities, and the distribution of the surplus between innovative countries and others.

\section{Implementing an intellectual property policy}

Until now my discussion of the links between innovation and intellectual property has been theoretical. One of the conclusions is that optimal property rights are continuous in all three dimensions (height, breadth and length) and that the implementation of an optimal property right in a country depends primarily on consumers' capacity to adopt innovation (cultural position, financial capacity, capital, etc.) and on that country's research and imitation capacities.

\subsection{How to choose the property rights to implement in a country}

Contrary to the recommendations of economic theory, at the operational level it is impossible to have different intellectual property rights for each innovation and in each country. Transaction costs are prohibitive and innovators have no certainty as to the size of the market for an innovation.

\subsubsection{Standard tools}


There are currently various intellectual property options available, which are supposed to cover the diverse types of innovation ${ }^{18}$. These options include patents, copyright, trademarks, etc. They vary widely, regarding not only the innovation that they protect but also their operational characteristics (length, breadth and height). Thus, the scope of intellectual property rights may differ: in copyright, where there is plagiarism, the explicit knowledge of the existence of a former literary work is necessary; in the case of the patent, there may be dependence on patents about which one was not aware. Shapiro (2000) uses the term "hold-up" to describe this situation. At a territorial level, a patent is valid only in those countries in which a PCT (Patent Cooperation Treaty) ${ }^{19}$ extension has been applied for, whereas protection by copyright is more common. The advantages of these standard tools is their universality, and hence the relative ease with which they can be used and their recognition throughout the world. Their drawbacks are that they are sometimes implemented in sectors or even countries where their effectiveness in terms of social optimum is weak or even negative. For example, as regards access to genes, there are risks of appropriation of life forms via an extension of patent rights on sequences that are too long. The social consequences can be disastrous, in respect of health (Aids) and food (famine) (Henry, Trommetter and Tubiana (2003)). The implementation of intellectual property rights can prove to be non-optimal because: the rights are not operational on a country scale; the rights are too strong or too weak in relation to the research capacities and/or the demand function of a country.

To limit the perverse effects of standard intellectual property rights and thus obtain a second-best social optimum, flexibilities exist. These flexibilities are generally implemented by government, for instance compulsory licences (e.g. on essential facilities), and antitrust institutions (e.g. Antitrust Division of the US Department of Justice) to limit situations of abuse of a dominant position. More simply, the conditions of intellectual protection of an innovation may be revised by law. The latter

\footnotetext{
${ }^{18}$ The choice of the rent is directly related to the trade-off between more innovation and more diffusion of this innovation, which is complex when one refers to a particular innovation. As Tirole (2003) points out: "it will be even more complex when one has to define an intellectual property protection regime that is valid for the entire economy".

${ }^{19}$ A unique procedure administered by the WIPO which, with reference to the Washington Treaty of 19 June 1970, allows for a patent to be filed simultaneously in all or some of the signatory countries of this convention. A single international application has the same effect as national applications filed in the countries covered (Source: http://hydre.auteuil.cnrs-dir.fr/dae/faitsetchiffres2003/\&\& lexique.html ).
} 
option is feasible only when the social costs of the perverse effect are higher than the costs for the firm incurred by unstable intellectual property rights. To be encouraged to invest in $R \& D$, firms need stable legal rules. Otherwise they integrate the instability (uncertainty) in their profit-maximizing model, which will tend to reduce their incentives to R\&D. The reasoning is the same for compulsory licences which, to be economically and socially effective, should not be used systematically.

The implementation of standard property rights can also lead to overlapping rights. Under-efficiency related to such rights may stem from rights that are too easily granted (height) or claims that are too easily accepted (breadth), or a combination of the two. In this context Shapiro (2000) defines "patent thickets" as situations in which a patent depends on a very large number of other patents ${ }^{20}$ and consequently entails risks of inefficiency due to: the existence of too many beneficiaries (Heller and Heisenberg (1998)) - the "multiple margin" phenomenon -; the fact that the thicket is a source of uncertainty - one of the patent owners may refuse to grant an operating licence and block future research -; and high transaction costs, the anti-commons tragedy (Heller and Heisenberg (1998)). In this context the tool consisting of "a licence on a pool of patents" seems the most appropriate for limiting the perverse effects. But pools of patents are generally used in the construction of standards or modular innovations (ex ante complementarities), since their ex post use is often equated to anticompetitive practices by antitrust authorities. In the past the use of licences on ex-post patent pools was reserved for the state, to boost economic sectors such as the aeronautics industry in the US in 1919 and the semi-conductor industry in the 1950s. Today these licences on ex post patent pools are proposed by private firms and theoretically justified by the work of Lerner and Tirole (2004). These authors show that granting licences on an ex-post pool consisting of partially substitutable rights can be socially optimal if they fulfil certain conditions, particularly the existence of individual licences on the patents comprising the pool. In other cases, the extrapolation of models of common agencies (Sinclair Desgagné (2001); de Villemeur and Versaevel (2003)) to matters of collective knowledge

\footnotetext{
${ }^{20}$ Golden Rice is a technology developed to enrich rice in Vitamin A, with a view to compensating for a chronic deficiency in populations whose staple food is rice. Three genes were inserted to complete the biosynthesis of beta-carotene, in addition to which the technology requires the use of transformation vectors, promoters and markers of resistance to antibiotics, all patented or covered by material transfer agreements (see below): a total of 70 items controlled by a dozen patent holders (Kryder et al. (2000)).
} 
management can be considered. They may explain the implementation, for example, of the clearing house mechanism ${ }^{21}$ in the US in the plant biotechnology field (Graf et al. (2001)).

\subsubsection{Non-standard tools}

Apart from the traditional tools of intellectual property and their related flexibilities, other tools can be proposed to protect innovations: sui generis intellectual property rights, licence contracts in open source technologies, etc.

* The use of sui generis rights is generally limited to well-defined sectors (as recommended by economic theory on optimal intellectual property rights). They are new tools, designed to be adjustable to particular innovations. Implementing a new right is costly but in these particular sectors the associated cost is inferior to the social cost relative to protection with a standard tool linked to flexibilities. Two examples: first, in 63 countries plant varieties (seeds) are protected by plant variety rights (PVR) issued by the Union for the Protection of New Varieties of Plants (UPOV); second, databases in Europe are protected by a sui generis right. In the former case the idea is to establish a right that is weaker than the patent in the scope of the protection, whereas in the latter case, since copyright is considered too weak to effectively protect databases, it is accompanied by a sui generis right that increases the breadth compared to traditional copyright.

* The licence contract in sectors where research is organized along the same lines as open source software. In this framework standard protection tools are used - usually copyright - but it is by way of the licence contract that the diffusion of innovations is facilitated. The initial developer's objective is to favour the development of cascading applications, while limiting the risks of private appropriation by others.

The aim of these non-standard rights is to protect the innovation while limiting the perverse effects of the standard right. The PVR guarantees the protection of the commercialized variety against

${ }^{21}$ Graf et al. (2001) explain that the implementation of a clearing house mechanism for the collective management of the patents of US universities in the plant biotechnology field depends on:

- limiting risks related to overlapping patents, to seek and propose licences on attractive patent pools and/or produce innovations in the public sector (on orphan plant varieties or aimed at developing countries);

- $\quad$ greater negotiating power to have access to patent licences held by large biotechnology multinationals. 
imitations, which is the necessary condition to ensure incentives to innovate, while guaranteeing access to the genetic resources composing it, for research and plant breeding purposes. This access is open, free-of-charge and automatic (i.e. without a contract) (Joly and Ducos (1993)). Such free access to genetic diversity has always been demanded by plant breeders, especially in Europe. In 1991 the PVR was amended. Legislators revised the definition of the breadth of intellectual property, which amounted to redefining the notion of imitation, to limit risks of private appropriation of plant varieties by GMO seed producers (Trommetter (2005)). Today an imitation is a variety that is essentially derived from a pre-existing variety. A minimal genetic distance must exist between two varieties for them to be considered as independent. The breadth of the PVR is therefore limited to the commercialized variety and to essentially derived varieties, contrary to plant varieties protected by patent (US with the Plant Patent Act and the Utility Patent), where the breadth primarily concerns all uses of the variety and therefore requires negotiation of a licence agreement.

The approach that led to the PVR corresponds to a research paradigm based on access to biological and genetic diversity, and to theoretical models of sequential and cumulative innovations (Scotchmer (1991, 1999 and 2005)) which reflect the organization of research in the seed sector in Europe. Today this model is found again in open source software, where access is free but contractualized to avoid risks of appropriation allowed for by current legislation ${ }^{22}$. The logic of copyleft licences for the use of open source-type software (Dequiedt, Ménière and Trommetter (2006)) is very similar to the PVR logic. To be able to use and alter open source software it is necessary to sign licence agreements that may have varying characteristics ${ }^{23}$. This may be a source of substantial transaction costs. To facilitate access to innovations, it is necessary to introduce contracts that limit the uses to which innovation can be put, especially private appropriation. Compared to the PVR which proposes automatic free access

\footnotetext{
${ }^{22}$ In open source software a variety of licences is proposed to users. These may prove to be antagonistic with regard to certain uses. Likewise, the PVR facilitates the diffusion of varieties in countries that are members of the UPOV, but limits diffusion in the US where protection is double, causing risks of dependency to be more frequent.

${ }^{23}$ A few examples of licences:

- GNU General Public Licence: this licence proposes free access and free amendments;

- BSD Licence (Berkeley Software Distribution Licence): this licence proposes free access, free amendments and free redistribution of amended programs;

- Mozilla Public Licence: this licence proposes free access, free amendments for personal use and the possibility of redistribution under MozPL licence.
} 
to the genetic diversity of commercialized varieties for all UPOV members, in the case of open source software access is contractualized, thus generating additional transaction costs.

The drawbacks of sui generis rights are primarily related to their credibility on the international scene. To be adopted by innovators, these rights have to be implemented in a minimum number of countries so that a minimum threshold can be reached for the size of the market accessible to the innovator. If the right is implemented in areas that are too limited, the only certainty is that innovators will abide by the rules of more constraining rights, to be able to reach a sufficient market area for their innovation, without risks of dependence. Hence, sui generis rights that are too weak can reduce effects on research, since the flexibilities that they allow will not be mobilized.

In the case of developing countries these sui generis rights have to be studied. The advantage of constructing a sui generis right is that it enables the legislator to take into account the specific characteristics of the research and development system, of the national demand and possibly also of environmental constraints. In the protection of plant varieties, use of a sui generis tool has often been interpreted as the implementation of the PVR in developing countries, but other sui generis protection systems can be developed. The Organization of African Unity (OAU) has proposed a system of sui generis protection which defines the conditions of access to biological resources, as well as community rights, farmers' rights and plant breeders' rights (OUA (1999)). Despite its shortcomings, this document was intended to take into account the particularities of plant breeding in the countries concerned. In most African countries the seed sector often remains empirical and local varieties, although new and distinct, are generally less stable and homogeneous than seeds in the North. But stability and homogeneity are the conditions needed to use the regular protection tools, the PVR or patent. The intellectual property system proposed by the OAU is weaker than the UPOV system in its height, that is, what can be protected, and it can be combined with other types of protection. The objective is to favour the diffusion of innovations from the North without precluding the development 
of traditional varieties in the South ${ }^{24}$. To that end, it is necessary for countries to grant authorization for commercialization, compatible with their research capacities. In seeking a social optimum, each country can define various conditions for a variety to be listed in the catalogue of commercializable varieties. In Europe commercialized varieties have to fulfil certain conditions for protection by the PVR (distinctness, uniformity and stability); in Africa a country can set up a PVR-type protection or a patent to attract innovations from the North, combined with a sui generis protection on traditional varieties, while simultaneously authorizing commercialization of the two types of seed ${ }^{25}$. Farmers are therefore free to choose the seeds they wish to use in their fields.

\subsection{Limiting the perverse effects by maintaining the positive effects of rights}

The existence of different rights to protect innovations should help to limit the perverse effects of property rights that are too generic and inflexible, in countries of the North and the South alike. The co-existence of different rights nevertheless impacts on future research capacities and future markets for innovations.

\subsubsection{Co-existence of different rights}

The fact the PVR or patents can be used to protect seeds obtained by breeding - that is, by crossbreeding rather than genetic manipulation - has led the EU to propose flexibility in Directive 98/44 on biotechnological inventions: the possibility of resorting to cross-compulsory licences in plant biotechnologies to solve disputes between private actors ${ }^{26}$. These licences guarantee protection for innovation, with "remunerated free access" to genetic resources. Thus, when innovators cannot produce an innovation without infringement of an existing patent, they can request a dependency

\footnotetext{
${ }^{24}$ Other tools are envisaged to protect traditional varieties. For example, Geographic Indication, recognized by the WTO, associates a product, a territory and, in certain cases, specific varieties used to produce it. For instance, in the case of the AOC Châtaignes d'Ardèche, the chestnuts are from local varieties of the Castanea sativa Miller, the list of which is defined in the technical regulations provided for in Article 1 of the 28 June 2006 Decree (Marchenais (2006), personal paper).

${ }^{25}$ Article 27/3b of the WTO TRIPS agreement provides for the combination of rights since it stipulates that: "Members shall provide for the protection of plant varieties either by patents or by an effective sui generis system or by any combination thereof ...". See 3.1 below.

${ }^{26}$ Directive 98/44, Section III on compulsory dependency licences.
} 
licence for the non-exclusive exploitation of the invention protected by that patent, in exchange for an appropriate licence fee and/or a cross-licence between the two innovations. If the patent holder refuses to grant a dependency licence, European Directive 98/44 stipulates that it may be compelled to do so by public decision (in France, the law courts). Even if the institution of a system of compulsory dependency licences between varieties protected by PVR and GMOs protected by patent limits the risks of impeding subsequent research, seed companies switch from a system of free access to one of payment for access. In Europe access to genetic diversity is no longer automatic, nor free, but remains a priority. Transposition of the biotechnology directive in French law, in December 2004, proposes another flexibility by adding an article to limit the scope of patent protection (Article / 613 5-3) ${ }^{27}$. The aim of this article is to guarantee access to genetic diversity, including GM varieties that contain one (or more) patented gene(s), since the patent covering a gene in a GMO is no longer extended to the entire plant. Free access exists to the genetic diversity of the GMO, minus the patented gene. Use of this freely accessible genetic diversity is facilitated by biotechnological innovations such as "marker assisted breeding” which make it possible not to select the results of cross-breeding in which the patented gene is present. Thus, in the transposition to French as well as German and Swiss legislation, access to genetic diversity is once again open, automatic and free-of-charge, but with other constraints, particularly on access to seed markets.

International conventions can also limit the use and diffusion of innovations. To favour the protection and diffusion of agricultural genetic resources, the FAO international treaty on phytogenetic resources takes into account the fact that different types of intellectual property exist, which have diverse effects on the genetic resources in innovations. If an innovator protects an innovation by PVR or any other sui generis system that allows free access to genetic diversity, there is a voluntary contribution to an

27 "Art. L. 613-2-2. - Subject to the provisions of Articles L. 613-2-1 and L. 611-18, the protection conferred by a patent to a product containing genetic information or consisting of genetic information extends to any way in which the product is incorporated and in which genetic information is contained and has the indicated function.

"Art. L. 613-2-3. - Protection conferred by a patent relative to a biological material which, through an intervention, has determined properties, extends to any biological material obtained from that biological material by reproduction or multiplication and endowed with those same properties.

"Art. L. 613-5-3. - The rights conferred by Articles L. 613-2-2 and L. 613-2-3 do not extend to the acts accomplished with a view to creating or discovering and developing other plant varieties." (Personnal translation) 
international compensation fund. If an innovator protects an innovation by patent, with a risk of blocking access to genetic resources, there is a compulsory payment to the compensation fund. There is therefore an incentive to maintain free access to the resources relative to the amount of compulsory compensation to the international fund. The purpose of this fund is to manage and preserve genetic resources and to finance operations of plant improvement in favour of countries of the South.

However, with changes in the status of agricultural genetic resources, only the plants covered by the FAO international treaty remain freely accessible. What about those not covered by the treaty and therefore covered by the convention on biological diversity? Take the case of the tomato, for instance, which is not covered by the international treaty. Access to genetic resources depends on the sovereignty of states and the usual contractual clauses with the provider of genetic resources. In contrast, the commercialized variety is freely accessible for competitors since it is covered by a PVR. In this context two situations are possible:

* The firm does not enter into a contract with the supplier of genetic resources and takes the risk of using the resource without authorization. Since there are multiple hybrid origins, it is very difficult to identify ex post the biological material effectively used in breeding programmes (local cultivars, protected varieties, etc.). A risk of free-riders therefore exists for the owners of the resource. This risk can be limited by implementing mechanisms of traceability to identify the material effectively used, for instance the certificate of origin and the process of disclosure of the origin of the biological material when the application for an intellectual property right and particularly for a patent is made ${ }^{28}$. However, depending on the definition of the origin of the material $^{29}$, the implementation of these certificates can very quickly become complex in the seed sector, due to multiple overlaps, with exponentially increasing transaction costs;

* The firm enters into a contract. It may be faced with particular clauses - e.g. "the material can be used in R\&D activities whose innovations will be protected by patent and not by PVR" - or equally tight constraints. For instance, the firm may be encouraged to protect its innovation with

\footnotetext{
${ }^{28}$ The implementation of these tools is under negotiation at the Convention on Biological Diversity

${ }^{29}$ Negotiations are under way at the FAO to define the notion of "origin of the material". Should a laboratory, whether public or private, be obliged to disclose the last transaction (the person or laboratory that gave it the material) or the first transaction on that material (who is the original owner of the material)?
} 
an IP system other than the PVR, since it is potentially the only one to pay a licence fee on its innovation. In this case it would want to limit the possibilities of hold-up of its innovation by competitors $^{30}$.

The PVR is still the tool for easy access to agricultural genetic resources but its influence may decline due to the change of status for basic genetic resources. This potential reduction of the role of the PVR in the protection of plant varieties will also impact strongly on future research. Thus, as Bellivier and Noiville (2006) point out: "the 'INRA 258' maize variety, created from two American, one Spanish and one French variety, could probably not have been developed without years of negotiations with the countries of origin had the Convention on Biological Diversity system not been applied".

This co-existence of various tools does not facilitate seed firms' access to the seed market. Wanting to distribute European seeds in the US is risky, to say the least, due to the fact that there are no compulsory cross licences with the US. Likewise, since France and Germany have more flexible legislation than other European countries, in transposing Directive 98/44 on the non-coverage of content they can modify the conditions of dissemination of French and German seeds throughout the rest of Europe. They could prove to be dependent on other varieties, in accordance with current legislation. Moreover, applications by European firms for PVR protection in the US are very few in number compared to applications for protection by the Plant Patent Act (UPOV (2005)) ${ }^{31}$. Likewise, the varieties developed by seed firms in the US and protected by the Plant Patent Act or the Utility Patent will be protected only by a PVR in Europe, if they are disseminated there (see Box 1).

Box 1: Dissemination of seeds between Europe and the US

\section{In Europe:}

* 3,077 PVR were granted in 2004, of which 507 to foreign residents, of which 21 from the USA.

\footnotetext{
${ }^{30}$ A limit of the PVR is that in the case of research on resistance, certain functions which are costly to identify and transfer can easily be copied by competitors. The notion of essential derivation should probably be extrapolated to these situations.

${ }^{31}$ These figures are biased by the fact that the conditions for commercializing seeds in the US are more flexible than in Europe, so that many varieties (primarily hybrid varieties) are commercialized there without being protected (secrecy).
} 


\section{In the USA:}

* 421 PVR were granted in 2004, of which 33 from foreign residents, of which 11 from the EU.

* 1,016 Plant Patent Act patents were granted in 2004, of which 588 to foreign residents, of which 455 from the EU

* over 200 Utility Patents were granted on plant varieties in 2004

Source USPTO and UPOV (2005)

\subsubsection{Creating research consortiums}

To avoid the risk of being blocked by intellectual property rights that are too far upstream and too broad, both public and private research institutions propose an alternative to the collective management of intellectual property and to patent pools: the creation of a new way of organizing research, based on new collective and cooperative relations in the pre-competitive phases. The objective is to define the operating rules of research consortiums so that: - they are economically and socially effective by limiting, for example, risks of opportunistic behaviour associated with asymmetries of information (moral hazards and adverse selection); - they are not subject to the rules of competition law: there is private access of the members of the network to certain information; there are some delays in the diffusion of certain information within the network; there is little or no coownership of patents.

Thus, the main objective of the creation of consortiums on structural genomics is to accelerate the production of new protein structures from the crossing of different partial gene sequences found in public databases (Williamson (2000)). Thus, in the framework of the Single Nucleotide Polymorphism (SNP) consortium, over 300,000 human SNPs have been put into the public domain (Williamson $(2000))^{32}$. This research is financed by private funds and is carried out by public and private research

\footnotetext{
${ }^{32}$ The members of the consortium are: Wellcome Trust; APBiotech; AstraZeneca PLC; Aventis; Bayer AG; Bristol-Meyers Squibb Company; F. Hoffmann-LaRoche; Glaxo Wellcome PLC; IBM; Motorola Novartis; Pfizer Inc; Searle; SmithKline Beecham PLC. The work financed by the consortium is carried out by four research institutes: Stanford Human Genome Center; Washington University; Wellcome Trust's Sanger Centre and Whitehead Institute. Each member's financial participation is US\$3m. Any new participant in the consortium has to pay this sum as an entry duty. The Wellcome trust contributed US\$14m (Williamson (2000)).
} 
institutes. The aim is to use these public data to discover interesting genes more quickly, for developing new drugs (patentable innovations), by cross-referencing different databases without having to worry about the existence or not of IP rights on the SNP used (i.e. leaving free access to sequences for all functions).

Likewise, the "Génoplante" contract (a French research consortium of public labs and private firms) provides for the more fundamental patents to be filed by research institutes and the more applied ones to be filed by private enterprises. The contract furthermore provides for free compulsory licences between members of the consortium.

Finally, the open source model is mobilized in biotechnologies where "open source biotechnology" refers to the possibility of extending the principles of commerce-friendly, commonsbased peer production exemplified by open source software development to the development of research tools in biomedical and agricultural biotechnology. Feldman (2004) notes that "fledgling efforts exist to establish open-source projects in biotechnology. Following copyleft, participants agree that advances in the technology must remain as openly available as the original technology".

Hence, within consortiums and networked research activities, the definition of rules is a prerequisite for each research project. As Cassier and Foray (1999) show, an absence of rules at the outset automatically leads to opportunistic behaviours and to the end of research networks. The introduction of rules is therefore necessary to limit moral hazard situations, since the partners' actions cannot all be observed. There is a twofold uncertainty on the real activity of genetic evaluation and on the dissemination of information to the members of the network. The rules on the conditions of participation and even exclusion from the consortium are therefore central. If there is a sharing of costs and results, the approach has two steps: participate or not in common research (choice between participating or not), then set the rules of sharing and the levels of each partner's research efforts, etc. The general conclusion is that the more intense the competition is downstream, the more a cooperative agreement can help to reduce the overall effort. This type of difficulty is partly resolved with models based on partial cooperation agreements (Bhattacharya and Sappington (1992); Bhattacharya and Guriev (2004)). 
In this system of research coordination, no patents are filed on the results of pre-competitive research phases. There is a contractualized free access to genetic diversity, whereas the PVR model proposes that access to genetic resources be free and non-contractual for seed companies and therefore without transaction costs. Patents on life forms and especially their excesses lead to contractualization (economically and socially necessary) of free access, the only guarantee of private non-appropriation of genetic resources and of a return to an organizational model close to the PVR.

\section{How can the TRIPS agreements be interpreted?}

In this section we analyse whether the construction and implementation of the WTO TRIPS agreements and the bilateral TRIPS+ agreements are consistent with the propositions in the first two sections. There we examined how IP rights can be defined and implemented so that innovations are achieved and diffused in a context of maximization of the social welfare.

\subsection{How to choose IP rights under the TRIPS agreements}

The TRIPS agreements require the implementation of a system of minimal intellectual property protection. This means that when it comes to intellectual property, a country can do more but cannot do less. To expand the area of the market for innovations in the North, developing countries can set up more restrictive IP rights. In other words, there is no superior threshold above IP rights. Nevertheless, two superior thresholds are recognized by the WTO and can be imposed by a country's government: the general interest endorsed by compulsory licence; and abuse of a dominant position sanctioned by the relevant authorities.

Concerning operationality, we will now focus on the implementation of Article 27 of the TRIPS agreement relative to patents. The aim is to generalize the patent system world wide, but at the same time to provide for flexibilities (primarily by limiting the height of patents), with: the possibility of 
excluding inventions from patentability, Article $272 .{ }^{33}$ and $273 . .^{34}$; the application of exceptions to the rights conferred, Article 30 and to a lesser extent Article 31.

Restrictions also exist on the possibility of excluding inventions from intellectual property; this is the case of plant varieties in Article $273 / \mathrm{b}^{35}$. This article stipulates that a country is obliged to grant rights on plant varieties, but provides for flexibility on the tool to implement since it authorizes recourse to sui generis rights. A known sui generis system to protect plant varieties is the PVR, but other systems can be implemented, such as the OAU system described above. ${ }^{36}$

Of the four points favourable to innovation, presented by Aghion and Howitt $(1998)^{37}$, very few are present in developing countries and we may wonder whether starting with the implementation of Point (4) "protection against ex post competition in the product market" is the most effective way to favour development and the diffusion of innovations in developing countries. On 30 November 2005, the WTO provided for a degree of flexibility in the implementation of these agreements, for the least developed countries: "least developed country members as a group were granted extension of transitional period for 7.5 years to apply the provisions of the TRIPS Agreement - that is, 'until 1 July

33 "Members may exclude from patentability inventions, the prevention within their territory of the commercial exploitation of which is necessary to protect ordre public or morality, including to protect human, animal or plant life or health or to avoid serious prejudice to the environment, provided that such exclusion is not made merely because the exploitation is prohibited by their law."

34 "Members may also exclude from patentability:

(a) diagnostic, therapeutic and surgical methods for the treatment of humans or animals;

(b) plants and animals other than micro-organisms, and essentially biological processes for the production of plants or animals other than non-biological and microbiological processes."

35 "However, Members shall provide for the protection of plant varieties either by patents or by an effective sui generis system or by any combination thereof."

${ }^{36}$ The TRIPS agreements allow for the co-existence of several rights, which should be favourable for the creation, diffusion and commercialization of traditional seeds.

${ }^{37}$ To sum up, the following are favourable for innovation:

1) competition for innovation;

2) ex ante competition in the product market;

3) diffusion of knowledge accumulated on the occasion of previous innovations;

4) protection against ex post competition in the product market.

If, as is often the case, the restriction of competition (4) is obtained by a temporary monopoly on the use of certain knowledge, Conditions (1), (2) and (3) are all affected adversely for innovation. 
2013, or until such a date on which they cease to be a least-developed country Member, whichever date is earlier' ". ${ }^{38}$

For the agricultural sector, a question relative to the adoption of IP rights is: do developing countries today have access to the most effective seeds for their agricultural production? The answer is: this depends on the IP system, on research and imitation capacities, and on the existing demand in the developing countries. This answer highlights the fact that the IP system is simply one of the elements that favour the creation and diffusion of innovations world wide.

The world seed market is currently considered to be worth US\$50bn, US\$30bn of which are traded commercially. GMO seeds currently account for US\$10bn. As regards research in agricultural biotechnologies, $96 \%$ of R\&D expenditures are made in OECD countries and $70 \%$ are by private enterprise. In this context, Box 2 presents contrasting situations. Some countries import varieties from the North, others far less so. In Argentina over $60 \%$ of the varieties protected by PVR are produced by local seed firms. This is therefore an effective tool for Argentina since it has allowed both diffusion of innovations from the North and the development of a competitive seed sector (owing to $R \& D$ activities). In countries which benefit from these transfers of varieties, some are totally reliant on R\&D in the North. For instance, in Kenya the 37 PVR of foreign origin concern rose varieties, as the production of roses for export is now being developed locally. Kenyan farmers are therefore simply producers under contract with major groups. These local producers hardly benefit from the value added and there seems little hope that this situation will change in the future. Even if the will to nurture fair trade exists, studies show that transport, storage and distribution absorb a large share of the value added. Production accounts for no more than 10\% of the sales price (anonymous (2005)). Moreover, because of low production costs, Ethiopia is actually a major competitor to Kenya.

In most countries of the South the institution of intellectual property has not boosted the local seed sector via technology transfer or direct foreign investments. Is this irreversible or are we in a transitional phase?

\footnotetext{
${ }^{38}$ This decision does not apply to pharmaceutical products, which LDCs are not required to fully protect until 2016 as a result of an extension granted to them in 2002 (Doha agreement).
} 
There is a risk of local seed firms disappearing and thus of local farmers becoming dependent on breeders in the North, which in the long run could prove to be under-efficient. To limit these risks, in addition to the flexibility related to the choice of a mode of protection, the TRIPS agreements enable countries to implement compulsory licences in the general interest (health, under-nourishment and poverty $)^{39}$. Such compulsory licences have a sphere of application which is generally limited to the borders of a country. But we have seen that many developing countries have capacities for neither research nor imitation, and are therefore unable to implement the threat of a compulsory licence. In the Doha declaration on the TRIPS agreement and public health, a flexibility clause is added: the possibility of benefiting from products manufactured at regional level is provided for - but the conditions of implementation of a compulsory licence are complex.

Box 2. Diffusion of innovations from countries of the North to developing countries in 2004

\section{In Latin America}

* Argentina: 230 PVR of which 114 by non-residents, of which 101 from countries of the North

* Brazil: 121 PVR of which 30 by non-residents, of which 26 from countries of the North

* Other (9 countries): 380 PVR of which 327 by non-residents, of which 209 from countries of the North

\section{In Eastern Europe}

* Russia: 417 PVR of which 8 by non-residents, of which 6 from countries of the North

* Other (14 countries): 504 PVR of which 128 by non-residents, of which 101 from countries of the North

\section{In Africa}

* South Africa: 277 PVR of which 198 by non-residents, of which 184 from countries of the North

* Kenya: 41 PVR of which 41 by non-residents, of which 37 from countries of the North

\footnotetext{
${ }^{39}$ Henry (2004): "In the case of a compulsory licence, a qualified public authority charges a patent holder to grant a licence to an operator nominated by the said authority, in exchange for a remuneration which it determines. This is a last resort, envisaged only if the patent holder takes advantage of its (temporary) monopoly position in relation to the public interest concerned.
} 
In Asia

* China: 87 PVR of which 4 by non-residents, of which 4 from countries of the North

* South Korea: 477 PVR of which 273 by non-residents, of which 270 from countries of the North

Source UPOV (2005)

Despite reservations regarding TRIPS, flexibilities do exist in these agreements, in both the IP tools and in their implementation (primarily compulsory licences, differentiations in the deadline for implementing the TRIPS, etc.). These flexibilities may allow for a second-best social optimum to be attained in a context of sustainable development. But are they really applied in developing countries?

\subsection{The TRIPS+ agreement}

The bilateral TRIPS+ agreements are free trade agreements signed between a developing country and either the US or the EU. These agreements are usually contracts in terms of which the developing country will implement intellectual property rights that go beyond the TRIPS agreement recommendations (primarily by overruling the flexibilities) and often beyond the IP rights of developed countries (e.g. by limiting recourse to compulsory licences ${ }^{40}$ ). In this context, the US and Europe seek to impose their IP system on developing countries, for example in the protection of plant varieties. Patents are supported by the US and PVR by Europe. The system of protection opted for by each country will have an impact at national level - on research, competition and markets - as well as international level by expanding -respectively reducing- the perimeter of the market for European innovations protected by PVR, to the detriment -respectively benefit- of innovations from the US, protected by patent. This race for bilateral agreements, between the EU and the US, does not take into account the real needs of developing countries in terms of intellectual property. For instance, imposing the PVR or patent does not protect local cultivars which in certain countries account for over

\footnotetext{
${ }^{40}$ Henry (2004): "In 1993, under pressure from the US, by an amendment to the law passed in the preceding year, Thailand agreed not to use compulsory licences, irrespective of the circumstances. This legal ban was lifted in 1999 when Thailand introduced into its law the TRIPS agreements concluded at the WTO in 1995".
} 
$80 \%$ of the seeds sown. What future is there for the seed sector in developing countries and what are the consequences for their farmers? Three scenarios can be envisaged:

* Scenario A, the patent: country X has weak R\&D capacities in the seed sector, associated with a system of patents on plant varieties. The future of its agriculture therefore depends exclusively on seeds produced abroad and possibly technology transfers for producing and/or carrying out seed innovations in the country. This means that there are risks of dependence of its agriculture on agri-chemical and seed companies from the North. In this scenario, trade advantages exist in country X's favour, but it is necessary to anticipate the distribution of this gain between the actors and, in particular, the amount of royalties paid to the innovator in the North (share of the surplus captured by the innovator).

* Scenario B, the PVR: a country has little R\&D in the seed sector but a PVR to protect plant varieties. It is totally dependent on seeds from the North if authorization to market seeds is associated with conditions of granting a PVR, which is the case for instance in France ${ }^{41}$. The consequences are then the same as in the case of the patent: the flexibility of the PVR compared to the patent cannot be mobilized by local selectors as their varieties do not fulfil the conditions of certification, and therefore of commercialization.

* Scenario C, the PVR associated with a sui generis tool for recognizing local cultivars ${ }^{42}$. In this context, two intellectual property rights can co-exist ${ }^{43}$ and two types of variety can be commercialized (improved varieties from the North and local cultivars). Any plant breeders from country $\mathrm{X}$ can use the genetic diversity of protected varieties in its own breeding programmes. The dependence is then less strong and above all less irreversible than in the case of patent protection.

Consequently, the IP system opted for impacts on the country's capacity to participate in the creation of future technical change, and therefore on its level of dependence, for its growth, on innovations

\footnotetext{
${ }^{41}$ This situation is actually more flexible in France, particularly for participative breeding. April 172007 the European council adopt a directive on "conservation varieties" that will facilitate the inscription on the common catalogue and the commercialisation of old and traditional plant varieties.

${ }^{42}$ Whether it is a sui generis system close to the OAU model or a Geographic Indication.

${ }^{43}$ Note that this co-existence of rights is consistent with Article 27/3b of the TRIPS agreement.
} 
produced in countries of the North. The above scenarios are a key element for the future development of farming world wide. IP issues should therefore be dealt with at the same level as negotiations on direct or indirect aid for agricultural production (Drouhin, Munier and Trommetter (2005)). This directly raises the question of: who benefits from the agreement?

* No evaluation has been performed yet of the winners and losers of the extension of IP to developing countries. Case studies do nevertheless exist, especially in Latin America, in which the links are identified between IP, research cooperation, and direct foreign investments. The few available results (Forero Pineda (2006); Roffe (2006)) show that developing countries are not the winners in these bilateral agreements. Roffe points out that: "The countries of the Andean Group (Bolivia, Colombia, Ecuador, Peru, Venezuela) have experienced higher royalty fees since the Uruguay GATT Agreement. There has been an increase in patent applications, but $85 \%$ still from non-residents - mostly from 5 countries including US, UK, Japan - so the patent system is not benefiting the people in these countries". Moreover, competition between developing countries is fuelled by the EU and the US, which can collaterally create imbalances in regional agreements such as the Andin Pact (Drexl (2005)) ${ }^{44}$.

* The bilateral TRIPS+ agreements and their consequences on R\&D in developing countries are therefore somewhat removed from the TRIPS philosophy and standard economic theories. In these contracts, taking the particular characteristics of developing countries into account is not a priority. We may well wonder what the incentives are for countries of the South to sign such bilateral contracts.

In a context of sustainable development, negotiations on intellectual property certainly have advantages in terms of growth, but they also entail risks for developing countries, particularly with the TRIPS+ bilateral agreements. Even though at the WTO level it was acknowledged that the TRIPS agreements were too restrictive for the poorest countries - so that these countries were given until 2013 (even 2016 for the pharmaceutical sector) to implement them - some of these countries have

\footnotetext{
44 "After the U.S. had forced Ecuador to agree on higher domestic IP standards, the Andean Community Court of Justice in Quito held that the bilateral agreement violated the law of the Community", Drexl (2005).
} 
nevertheless signed TRIPS+ agreements with the USA or EU. Those countries now have rights out of all proportion to their R\&D capacities and their national demand functions.

\section{Synthesis and conclusions}

In this paper I have discussed the fact that economists define optimal IP rights as a continuum of options in three dimensions: height, breadth and length. At the operational level we have seen the impossibility of multiplying rights indefinitely (due to prohibitive transaction costs), as well as the use of a limited number of IP tools which have led to the implementation of flexibilities. These flexibilities are designed to limit certain perverse effects of rights ill-adjusted to the characteristics of some economic sectors (agricultural biotechnologies, pharmacy, etc.). They serve to offset the incompleteness of the system of IP rights in relation to possible types of innovation and to the characteristics of the countries in which they are developed.

The examples developed in this paper show the extent to which a country's choice of an IP system and related flexibilities has to be made strategically in relation to certain characteristics: capacities for imitation, research and adoption of innovation by consumers, size of national markets, capacity of access to international regional markets, capacities to enforce the IP systems in place (credibility of the law), and so on. Flexibilities necessarily have a cost but which has to be compared to the cost for society had they not existed. They are moreover included in the TRIPS agreements, even if the implementation of the compulsory licence in the Doha agreement on drugs seems particularly complex and therefore a source of high transaction costs.

These flexibilities - justified by economic theory due to the incompleteness of the IP rights system in some countries - are nevertheless challenged in the case of bilateral TRIPS+ agreements. In exchange for relinquishing them, the US and EU undertake to facilitate developing countries' exports, primarily of goods from primary production and therefore with a low value added. Is this reasonable in a sustainable development approach? The answer is clearly no, for there are risks of the developing countries remaining constrained to produce these goods with a low value added, since the North still has the monopoly on innovation. Apart from some countries - including, inter alia, India, China and 
Brazil - which have already adopted rights compatible with their research capacities, the risks are high.

\section{Bibliography:}

Aghion, P. and Howitt, P. (1998). “Endogenous growth theory”. MIT Press. Cambridge (Mass).

Anonymous (2005). “Cut flower blooms for ACP producers”. Spore. n¹19. pp. 3.

Bellivier, F. and Noiville, C. (2006). "Contrats et vivant. Le droit de la circulation des ressources biologiques”. col. Traité des contrats. Paris. LGDJ. 321 p.

Bhattacharya, S. and Sappington, G. J. (1992). "Licensing and the Sharing of Knowledge in Research Joint Ventures.” Journal of Economic Theory.

Bhattacharya, S. and Guriev, S., (2004). "Knowledge Disclosure, Patents and Optimal Organization of Research and Development." STICERD - Theoretical Economics Paper Series /2004/478. Suntory and Toyota International Centres for Economics and Related Disciplines. LSE.

Billette de Villemeur, E. and Versaevel, B. (2003). "From Private to Public Common Agency". Journal of Economic Theory. 11(2). pp. 305-309.

Cassier, M. and Foray, D. (1999). “La régulation de la propriété intelectuelle dans les consortiums de recherche: les types de solutions élaborées par les chercheurs.” Economie Appliquée LII(2): 155182.

Dequiedt, V., Menière, Y. and Trommetter, M. (2006). “Collective Intellectual Property Right”s. Working Paper INRA GAEL. Grenoble. 20 pages

Drexl, J. (2005). “The Evolution of TRIPS : Toward Flexible Multilateralisme”. Workshop "The TRIPS Agreement : European and Latin American analysis of the last ten years”. Buenos Aires. 18 pages. 
Drouhin, N., Munier, B. and Trommetter, M. (2005). "Banc d'essai des modèles et des simulations d'échanges internationaux agricoles: leçons pour les négociations”. Rapport intermédiaire. Cabinet Carles Rheims. Paris. 30 pages.

Forero Pineda, C. (2006). "The impact of stronger intellectual property rights on science and technology in developing countries”. Research Policy. 35. pp. 808-24.

Geroski, P. (1995). “Markets for technology: Knowledge, innovation and appropriability”. Handbook of the Economics of Innovation and technological Change. P. Stoneman. Blackwell: 90-131.

Gilbert, R. and Shapiro, C. (1990). "Optimal patent length and breadth". Rand Journal of Economics. vol. 21. pp. 106-112.

Graff, G., (2001). “An intellectual property clearinghouse for agricultural biotechnology.” Nature Biotechnology Vol.19 (December). 1179-1180 (http://biotech.nature.com).

Heller, M. and Eisenberg, R. (1998). "Can Patents Deter Innovation ? The Anticommons in biomedical Research”. Science 280 (may): 698-701.

Henry, C. (2004). "Propriété intellecutelle et développement ou comment imposer au mon un système perverti”. Working paper CECO. Ecole Polytechnique. Paris. 20 pages.

Henry, C., Trommetter, M. and Tubiana, L. (2003). "Innovation et droits de propriété intellectuelle : quels enjeux pour les biotechnologies ?’. In: Tirole, J. ; Henry, C. ; Trommetter, M. ; Tubiana, L. ; Caillaud, B., (éd.), Propriété intellectuelle. Rapport du "Conseil d'Analyse Economique". nº41. Paris: La Documentation Française. pp.49-112.

Joly, Pierre Benoit and Ducos, Chantal (1993). "Les Artifices du Vivant: Stratégies d'innovation dans l'industrie des semences”. Paris: Economica.

Kryder, R.D., Kowalski, S.P. and Krattiger, A.F. (2000). “The intellectual and technical property components of pro vitamin-A rice, (Golden Rice ${ }^{\mathrm{TM}}$ ) a preliminary freedom-to-operate review”" ISAAA Brief N0. 20. Ithaca: ISAAA 
Langinier, C. and Moschini, G.C. (2002). “The Economics of Patents: An Overview”. Intellectual Property Rights and Patenting in Animal Breeding and Genetics. CAB International.

Lerner, J. and Tirole, J. (2004). “Efficient Patent Pools”. The American Economic Review. Vol. 94. n³. pp. 691-711.

Masters, W. (2004). "Rewarding Innovation in African Agriculture Cash prizes for technological breakthroughs”. Workshop on Innovation in the Life Sciences: Intellectual Property and Public Investment for Pharmaceuticals and Agriculture. Earth Institute. University of Columbia. New York. USA. May. 20 pages

Roffe, P. (2006). “El acuerdo de los ADPIC Y la tranferencia de tecnología”. Workshop “The TRIPS Agreement : European and Latin American analysis of the last ten years”. Buenos Aires. 29 pages.

Scotchmer, Suzanne (2005). “Innovation and Incentives”. Cambridge: MIT press.

Scotchmer, S. (1991). "Standing on the schoulders of giants: cumulative research and the patent law." Journal of economic perspectives. 5(1). pp. 29-41.

Scotchmer, S. (1999). "On the optimality of the patent renewal system”. Rand Journal of Economics (30). pp181-196.

Shapiro, C. (2000). "Navigating the patent thicket : cross licenses, patent pools, and standard-setting". in A.B. Joffe and J. Lerner eds. Innovation Policy and the economy. MIT Press. Cambridge (Mass) : 119-150.

Sinclair Desgagné, B. (2001). "Incentives in common agency”. Working paper nº6. CIRANO. Canada. 35 pages.

Tirole, J. (2003). “Protection de la propriété intellectuelle : Une Introduction et Quelques Pistes de Réflexion” . In :Tirole, J. ; Henry, C. ; Trommetter, M. ; Tubiana, L. ; Caillaud, B., (éd.) Propriété intellectuelle. Paris. Documentation Française. pp. 5-48.

Trommetter, M. (2005). “Biodiversity and international stakes : a question of access ?” Ecological Economics. vol. 53. $n^{\circ}$ 4. pp. 573-583 
UPOV (2005). "Plant variety protection statistics". Document prepared by the office of the Union. UPOV. Genève. 27 Octobre. 16 pages.

Williamson, A.R. (2000). "Creating a structural genomics consortium”. Nature structural genomics. Supplement. pp.953 